JINOTEP Vol 8 (3) (2021): 299-309

DOI: $10.17977 /$ um031v8i32021p299

JINOTEP (Jurnal Inovasi Teknologi Pembelajaran)

Kajian dan Riset Dalam Teknologi Pembelajaran

http://journal2.um.ac.id/index.php/jinotep/index

\title{
VIRTUAL COLLABORATIVE LEARNING FOR IMPROVING STUDENTS' ENGLISH COMMUNICATION ABILITY IN PRIMARY SCHOOL LOEI THAILAND
}

\author{
Nur Musa'arah, Riska Widiyanita Batubara \\ Pendidikan Bahasa Inggris-Universitas Muhammadiyah Gresik
}

\section{Article History}

Received: 15-09-2021

Accepted: $30-10-2021$

Published: 01-11-2021

\section{Keywords}

Communication Ability;

Primary Students;

Virtual Collaborative

Learning

\begin{abstract}
Abstrak
Penelitian ini bertujuan untuk menganalisis efek perlakuan virtual collaborative learning (VCL) dalam meningkatkan kemampuan komunikasi siswa dalam Bahasa Inggris. VCL adalah metode belajar-mengajar sederhana yang mengharuskan siswa untuk bekerja sama dan berdiskusi dalam kelompok atau pasangan secara virtual sehingga mudah dipahami oleh siswa sekolah dasar di Thailand. Dalam penelitian quasi-experimental ini, desain time-series yang digunakan adalah masing-masing tiga kali pre-test dan post-test kepada dua belas siswa dari dua sekolah berbeda di Thailand. Data penelitian yang terkumpul dianalisis secara deskriptif. Hasil penelitian menunjukkan bahwa kemampuan komunikasi Bahasa Inggris siswa meningkat sekitar 48\%. VCL juga meningkatkan kepercayaan diri siswa Thailand dalam berkomunikasi menggunakan bahasa Inggris. Penelitian ini juga menemukan potensi penggunaan VCL karena pelajar diusia muda lebih tertarik untuk belajar secara kolaboratif dengan lingkungan dan teman baru.
\end{abstract}

\section{Corresponding author:}

Nur Musa'arah

Address: Dusun Mando RT 01 RW 05, Desa Pandu

Kec. Cerme, Kab. Gresik, Kode Pos 61171.

Instansi: Pendidikan Bahasa Inggris, Universitas Muhammadiyah Gresik

E-mail: nurmusaarah_180403@umg.ac.id

\begin{abstract}
This study was carried out to analyze the effect of virtual collaborative learning (VCL) for enhancing and encouraging students to improve their English communication ability. VCL is a simple teaching-learning method that requires students to work and discuss in groups or pairs virtually which are easy to understand by primary Thai students. In this quasi-experimental research, a timeseries design that used three times in each pre-test and post-test were applied to collect data from twelve students from two different schools in Thailand. The data collected were analyzed descriptively. The findings of the study showed that all respondents had improvements in their English communication ability with around $48 \%$ of improvements. The VCL was also improved Thai students' confidence in communicating using English. This study had also found the potential use of VCL as young learners had more interest in learning collaboratively with new environments and friends.
\end{abstract}

2021 Universitas Negeri Malang

p-ISSN 2406-8780

e-ISSN 2654-7953 
300JINOTEP (Jurnal Inovasi dan Teknologi Pembelajaran) Kajian dan Riset dalam Teknologi Pembelajaran Vol.8, No.3, November 2021, Hal. 299-309

\section{INTRODUCTION}

English communication ability is one of the important abilities in life. Khatib and Nooreiny (2014) stated that English communication ability is very important in academic and professional lives. Students are required to communicate well in their native and also international languages. People assume that someone who fluent in English communication is a smart person. Rao (2019) argued that today, individuals should dominate communication skills to gain success in their respective fields since communication skills play a vital role to acquire achievements in all fields, such as science, technology, health, entertainment, business, and others. This also is essential in the teaching-learning process. Palos and Merima (2014) also stated that one of the most important variables which influence the learning process is communication ability. The teaching-learning process will be successful if both communicators are able to communicate well. As stated by Djonnaidi, Wahyuni, and Nova (2021) that good communication ability is determined by communicators' speaking skill with mutual understanding. In reality, many EFL students are facing problems in mastering communication ability. Al Hosni (2014) proposed that regardless of how EFL students know about the English Language, they will still confront numerous troubles in communication. The examples of students' problems in communication include worrying about making mistakes and lacking vocabulary which leads to a lack of confidence. This would happen if students rarely practice especially for their active skills which consist of listening exercises and speaking practices. Besides, students who are reluctant to communicate with other people will make matters worse (Januariza and Suswati, 2016). In addition, the wrong teaching method applied by the teacher would also make the students' communication problems worsened.

Thai students are no different. In fact, many Thai students could not communicate using English effectively (Jaiyai et al., 2005). Most of the students in Thailand have problems with their English skills, especially in speaking and listening which are affecting their English communication ability. Biyaem (1997) argued that lack of confidence and lack of opportunity make Thai students' English communication ability worsened. Thai students do not have opportunities to communicate with their teachers and classmates using English, because their mother tongue affects their English pronunciation. This is strengthened by Punthumasen (2007) who found that most Thai students do not want learning English since it is boring and furthermore teaching approach is not fascinating. In addition, there are insufficient intriguing English books and materials which can urge them to study. As Prapphal (2003) stressed, the lack of utilizing technology in innovative learning activities contributes to the Thai students' problem in communication ability.

Virtual learning had been more famous and worthwhile in this Covid-19 pandemic. As an instrument that permits figuring out how to proceed learning process without unnecessary danger of virus infection, virtual learning becomes a new way of learning for all students, especially for Thai learners. Virtual learning should involve modern philosophy and modern technology. As Kawinkoonlasate (2020) conclude that virtual learning can overcome the students' boring matter effectively, interest, and bring them to the new learning environment. This also enhances students' opportunity to enggage in self-directed learning (Daar \& Nasar, 2021). Virtual learning ought to be collaborating each other, tackling complex issues, critical thinking, creating various types of communication and leadership skills, while further developing inspiration and efficiency. The combination of virtual learning and technology in the classroom allows teachers and learners to enhance crucial skills for current life.

One of the best methodologies to conduct virtual learning for the students in Thailand is Virtual Collaborative Learning (VCL).VCL is technology-based learning where participants should work together as a group to construct and share knowledge. Collaborative activities in virtual learning lead to positive student 
communication performance outcomes. It can help students actively produce critical and metacognitive thinking and increase students' creativity for problem-solving. It can also lead students' persistence to a greater degree, as well as decreasing the time needed for learning. Loes, C.N. et al. (2017) concluded that learning together advanced the positive communications. Harsley, R. Et al. (2017), Cho, Y.H and Lim, K.Y. (2017), Purcher P. Et al. (2016), Berns, A. Et al. (2013), and Ibanez, M.B. Et al. (2012) also agreed that collaborative learning usually giving greater achievement result for students when compared with individual learning.

In VCL, one of the most popular activities to be conducted in the classroom is Cooperative Learning Structures (CLS). According to Jhonson, Jhonson, and Stanne (2000), CLS is a strategy that plays a role play. Role-play is an activity that should change one's conduct to assume a role, to fill a social role, or planned to act in an adopted role. For example, the students will present in pair, one student will be a tutor who asks questions and the other students will be a tutee who answers the questions. But the two of them had to switch roles afterwards. Moreover, another example is when a group of three students that the first student plays a customer role in a shop, the second student plays a shop employee, the third student plays cashier role. CLS has clear and simple rules and instruction which is easy to understand by primary Thai students. Considering the very basic knowledge and ability of Thai students and also the limited English teacher in Thai primary school, CLS is one of the best methods to improve Thai students' communication ability than the other methods of collaborative learning. There are some previous studies that attempted to find out the use of CLS in teaching EFL students. However, the subject of the studies were college students. For example, the studies of Xin and Yunus (2019) and Cottell andBarbara (1994) showed that Cooperative Learning Structures are beneficial for students because students' SVA test achievement improves significantly. It can improve the students' language skills, teamwork and also interpersonal skills. In contrast, this study tries to find out the use of CLS in English teaching for primary students. This study focuses on the effectiveness of VCL for improving students' English communication ability in two schools, Bansubjaroen School and Wangnampu School in Loei, Thailand.

\section{Literature Review \\ Virtual Learning}

Virtual learning is a broader dimension of online courses with an online environment (Yonas and Mitike, 2020). This means that the characteristics of virtual learning are distance and internet connection. As mentioned by Kawinkoonlasate (2020) and Homan and Macpherson (2005) that virtual learning is a learning process using technology such as devices and internet connections as well as electronic learning materials which is interactive and downloadable. It enhances learning activities through the technology use and the internet. The teaching activities in the virtual learning environment commonly use instruction in most and physically separated.

Virtual learning is really beneficial for students. It gives an opportunity to the students to search and find many more resources for learning. According to Anderson (2006), virtual learning gives the opportunity to the students to interact with the many sources of learning that can improve students creativity. In addition, the connectivity between students helps them to communicate and learn each other which can increase students' motivation, ability in performances and their confidence. Students can support and help each other. They will also improve their knowledge through communication. Those ways are the great benefit of virtual learning. (Yuan and Kim, 2014). However according to Ningsih (2020), virtual learning with conventional learning method will impact the learners' understanding. This is because the conventional learning method usually has limited interaction between learners and teacher.

\section{Collaborative Learning}

Collaborative learning is a learning together process that consists of two or more people for solving problems, completing tasks, or learning new concepts (Fitriasari, N.S. Et al., 2020). Collaborative learning is beneficial for student's 
development. It makes students able to express their ideas, articulate thinking, develop representations, elaborate and engage students' knowledge in a social matter (Hernandez, Marcedes, and Pablo, 2014). It strengthened that interactions must happen to activate the cognitive mechanisms which produce explanations, agreements, knowledge explicitness and negotiation. This process allows everyone to learn through people experiences. There are other advantages, such as academic, psychological and social benefits different stages that already found and explained in previous studies (Johnson, Johnson \& Holubec, 1993; Roberts, 2005; Guitert, 2011; Hernández-Sellés \& Muñoz-Carril, 2012; Samsul, 2020).

Knowledge arises from human relationships. Knowledge is a result of social processes in historical and cultural contexts. Collaborative activities are based on three principles (Chandra, 2015):

a. The primary focus of instruction is students. It is similar with students centered learning which the teacher role is to guide and supervise students. Students will be given responsibility for the learning path by imparting to their skills which aims to develop learner autonomy and independence.

b. The primary importance includes interaction and "doing". Interaction helps students to train their communication ability. "Doing" is the activities that require students to move around and be active.

c. Working in groups has become an important method in learning. Working in a group or pair can increase the amount of student practice, train the learner's confidence, encourages students to cooperate with one another, learn from one another a lot, and others. The communication between students will go well if the students are paired or grouped.

Jhonson, Jhonson, and Stanne (2000) mentioned that researchers already developed many kinds of collaborative learning, but one the most popular activities is Cooperative Learning Structures (CLS). CLS is a strategy that plays a role play. Role-play is an activity that should change one's conduct to assume a role, to fill a social role, or planned to act in an adopted role. For example, the students will present in pairs, one student will be a tutor who asks questions and the other students will be a tutee who answers the questions. However, the students had to switch roles afterwards. Moreover, another example is when a group of three students that the first student plays a customer role in a shop, the second student plays a shop employee, the third student plays a cashier role.

\section{Bansubjaroen School (school condition based on the teachers' perspective)}

Bansubjaroen School is a primary public school that was established as an official school starts from May 1971. Bansubjaroen School is located in the Moo 2, Huai Siseaet Sub-District, Phu Luang District, Loei, Thailand. This school consists of kindergarten 3 until primary school grade 6 . The total of the students is twenty-one students include five students in the kindergarten, three students in the first primary, three students in the second primary, two students in the third primary, three students in the fourth primary, two students in the fifth primary, and two students in the sixth primary. This school has only two mathematics teachers and one science teacher, without an English teacher. Whereas, the subjects that are taught are Mathematics, English, Science, Thai Language, Social, and Art. The English lesson is taught three times a week with an hour per meeting.

English teacher has an important responsibility for ensuring that students learn proper English materials. However, as mentioned earlier, there is no English teacher to teach the subject in Bansubjaroen School. There are no capable teachers in teaching English with English educational background. In addition, most teachers in Bansubjaroen School cannot speak English fluently. Therefore, most of the time they only utilize google translate for helping them teaching English to the students. As a consequence, English in Bansubjaroen School is taught with conventional teaching and used old fashioned grammar being given the highest priority. As the result, the students feel bored easily in learning English.

\section{Wangnampu School (school condition based on the teachers' perspective)}

Wangnampu School is a primary public school that was established in May 1985. This school is located in the Moo 3, Huai Siseaet Sub-District, Phu Luang District, Loei 
Musa'arah - Virtual Collaborative Learning... 303

Province. Wangnampu School consists of kindergarten 2, kindergarten 3 until the sixth primary with the total number of students is twenty-four students. The students include four students in kindergarten 2, three students in kindergarten 3, two students in the first primary, sixth students in the second primary, fourth students in the third primary, three students in the fourth primary, and one student in each fifth and sixth primary. This school has one kindergarten teacher, one Thai teacher, and an English teacher. However, there are eight subjects taught include Mathematics, English, Science, Thai Language, Social, History, PE Class, and also Art Computer. The English lesson is taught five hours per week.

Wangnampu School has one English teacher who can help students to learn English. The teacher usually uses conventional teaching and old fashioned grammar being given the highest priority which makes the students feel bored easily in learning English. Sometimes, the English teacher also applies active activities such as learning vocabulary and drawing. However, the teacher never tries to use collaborative learning for the teaching-learning process. Therefore, teaching and learning outcomes cannot be maximized.

Considering the very basic knowledge and ability of Thai students and also the limited English teacher in the Thai primary school, CLS could be the one of the best methods to improve Thai students' communication ability than the other methods of collaborative learning. There are some previous studies that attempted to find out the use of CLS. However, the subject of the studies were college students. For example, the studies of Xin and Melor (2019) and Cottell and Barbara (1994) showed that Cooperative Learning Structures are beneficial for students because students' SVA test achievement improves significantly. It can improve the students' language skills, teamwork and also interpersonal skills. In contrast, this study tries to find out the use of CLS in English teaching for primary students in two different schools. This study focuses on the effectiveness of VCL to improve students' English communication ability in two different Thai schools, Bansubjaroen School and Wangnampu School.

\section{METHOD}

This study utilized the quantitative approach research methods. This study used a quasi-experimental approach One Group TimeSeries Design. The data was collected by a communication performance test in two treatments. The first treatment used virtual conventional learning and continued with VCL. The tests are conducted repeatedly during the learning activities in a semester. The One Group Time-Series Design (Leedy \& Ormrod, $2005)$ is described in Table 1.

$\mathrm{O} 1, \mathrm{O} 2, \mathrm{O} 3$ are the results of students' communication performances after virtual conventional learning. While, O4, O5, O6 are the results of students' communication performances after VCL. $\mathrm{X}$ is the treatment using VCL. This research was conducted in Bansubjaroen School and Wangnumpu School, Loei, Thailand through Virtual Meeting Application. The population of this research were a combination of students in the Bansubjaroen School and Wangnumpu School, Loei, Thailand in the odd semester of $2020 / 2021$. The researcher chose students in the grade 4,5, and 6 classes in both schools with the total students of 12 students. There were two variables in this study. The independent variable was VCL and the dependent variable was students' communication ability. This research used communication performance tests as instruments. The scoring criteria included pronunciation, grammar, vocabulary, fluency, and comprehension that developed from the Oral Proficiency Scoring Categories proposed by H. Douglas Brown.

The way of score conversion:

$$
\frac{\text { Gained Score }}{\text { Maximum Score }} x \text { Weight (100) }
$$

After that, all normally distributed and homogeneous data were analyzed using ANOVA. Statistical testing was carried out at a significance level of 0.05 (P-value $<0.05$ ). Analysis technique data using the IBM SPSS Statistics 25 statistical program.

Table 1. The One Group Time-Series Design

\begin{tabular}{llllllll}
\hline Group & \multicolumn{7}{c}{ Time $\rightarrow$} \\
\hline $\begin{array}{l}\text { Group } \\
1\end{array}$ & O1 & O2 & O3 & X & O4 & O5 & O6 \\
\hline
\end{tabular}




\section{RESULTS}

The two research instruments, three times pre-test and three times post-test were utilized to collect data. The entire data collected were tabulated using Oral Proficiency Scoring Categories proposed by H. Douglas Brown and analyzed descriptively. The scores of all twelve students in the pre-tests were compared with their post-test scores. The scores were calculated by the score conversion formula. The communication performance tests was carried out six times during the learning activities. Three communication performance tests conducted before VCL and the other three tests conducted after VCL. After the process of converting the score, the average score of each test was found.

The results are $\mathrm{O} 1=\mathrm{O} 2=\mathrm{O} 3<\mathrm{O} 4=\mathrm{O} 5=\mathrm{O} 6$. The students' pre-test and post-test scores showed constantly between $\mathrm{O} 1, \mathrm{O} 2, \mathrm{O} 3$ and between $\mathrm{O} 4, \mathrm{O} 5$, and $\mathrm{O} 6$. The $\mathrm{O} 1, \mathrm{O} 2, \mathrm{O} 3$ represent the first, second, and third communication performance tests before the VCL (pre-tests). The O4, O5, O6 represent the first, second, and third post-tests. The results of communication performance tests before and after the treatment are shown significantly different. The figure of the descriptive analysis of students' communication skills in English result is presented in Figure 1. The students' pre-test communication score of both schools from Bansubjaroen English teacher showed 1.4 points (maximum score of 5) or around 29 out of 100 contrast with students' post-test score that was 4.2 points or around 84. Similarly, students' pre-test score from Wangnampu English teacher was 1.5 points or about 30 and 4.3 points or around 86 after

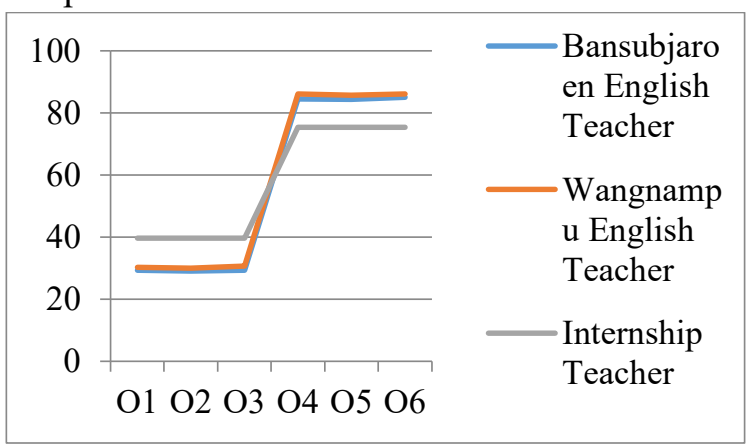

Figure 1. Average of students' communication performance results convertion for post-test score. In the same way, the Internship teacher gave 2 points in average or about 40 for students' pre-test scores and 3.8 points or about 75 for students' post-test scores.

Prior to the implementation of VCL, students' communication skills in English from all teachers were quite low, with an average score of 1.6 points or about 33 on each criteria, in three different tests. Meanwhile, after the implementation of VCL, students' communication skills in English in both schools increased, to an average of 4 or about 81 on each criteria, in three different tests. The students' scores of both schools from all English teachers increased from pre-test scores to the post-test.

The percentage of students' confidence from the number of students who volunteered to perform before and after the implementation of VCL showed a difference. From the data, only one student volunteered to perform in the first pre-test $(\mathrm{O} 1)$. In the second and third pre-tests (O2 and $\mathrm{O} 3$ ), there were 2 students who volunteered to perform before the implementation of VCL from the two schools. However, after the implementation of VCL, there are 10 students or about $83.33 \%$ who volunteered to perform in the first and second post-tests (O4 and $\mathrm{O} 5)$. In the last post-test (O6), eleven students volunteered to perform. The percentage difference is presented in Figure 2.

The data collected show that there is a significant difference in students' confidence performing their communication ability in front of the class.

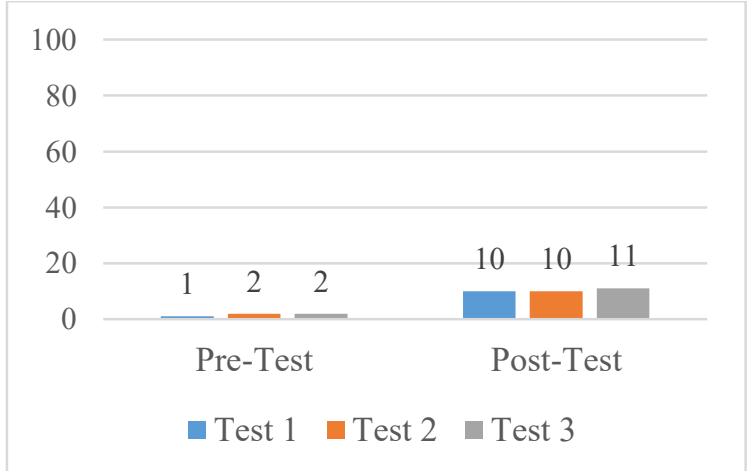

Figure 2. The Percentage of Students' Number who Volunteered to Perform Before and After The Implementation of VCL 
Musa'arah - Virtual Collaborative Learning... 305

Table 2. Test of Homogeneity of Variances

Levene

Statistic df1 df2 Sig.

Score Based on

\begin{tabular}{lllll} 
Mean & 0,204 & 5 & 66 & 0,960 \\
\hline
\end{tabular}

The difference showed from the average score of pre-tests and post-tests. It was only $13,88 \%$ of students volunteered to perform in front of the class. It means only around two students had the confidence to perform. Contrastly, the post-tests average score showed that $86,11 \%$ or about 10 students had confidence in performing in front of the class virtually. The students' confidence in performing in front of the other students from two different schools, two English teachers from Thailand, and also an Internship English teacher virtually after the VCL treatments were much better than the students' confidence before the treatments.
Table 3. The results of the analysis of variance (ANOVA) of students' communication skills in English

\begin{tabular}{llllll}
\hline & $\begin{array}{l}\text { Sum of } \\
\text { Squares }\end{array}$ & Df & $\begin{array}{l}\text { Mean } \\
\text { Square }\end{array}$ & F & $\begin{array}{l}\text { Sig } \\
\text {. }\end{array}$ \\
\hline Between & 43201, & & 8640,3 & 437, & 0,0 \\
Groups & 747 & 5 & 49 & 663 & 00 \\
Within & 1302,9 & & & & \\
Groups & 73 & 66 & 19,742 & & \\
& 44504, & & & & \\
Total & 720 & 71 & & & \\
\hline
\end{tabular}

The table of Homogeneity of Variances test shows that the P-value (sig) based on Mean $=0.960>\alpha=0.05$. This means that all samples $(\mathrm{O} 1, \mathrm{O} 2, \mathrm{O} 3, \mathrm{O} 4, \mathrm{O} 5$, and $\mathrm{O} 6)$ come from the same variance (homogeny) populations. The data distribution of students' English communication ability was normal and homogeneous (P-value $>\quad 0.05$ ). The Homogeneity of the Variances tests table is presented in Table 2.

Table 4. Mean Difference

\begin{tabular}{|c|c|c|c|c|c|}
\hline & (I) group & $(\mathrm{J})$ group & (I-J) & Std. Error & Sig. \\
\hline \multirow[t]{30}{*}{ Bonferroni } & pre-test 1 & pre-test 2 & 0,4417 & 1,8139 & 1,000 \\
\hline & & pre-test 3 & $-0,1333$ & 1,8139 & 1,000 \\
\hline & & post-test 1 & $-48,8833 *$ & 1,8139 & 0,000 \\
\hline & & post-test 2 & $-48,6667 *$ & 1,8139 & 0,000 \\
\hline & & post-test 3 & $-49,1083 *$ & 1,8139 & 0,000 \\
\hline & pre-test 2 & pre-test 1 & $-0,4417$ & 1,8139 & 1,000 \\
\hline & & pre-test 3 & $-0,5750$ & 1,8139 & 1,000 \\
\hline & & post-test 1 & $-49,3250 *$ & 1,8139 & 0,000 \\
\hline & & post-test 2 & $-49,1083 *$ & 1,8139 & 0,000 \\
\hline & & post-test 3 & $-49,5500 *$ & 1,8139 & 0,000 \\
\hline & pre-test 3 & pre-test 1 & 0,1333 & 1,8139 & 1,000 \\
\hline & & pre-test 2 & 0,5750 & 1,8139 & 1,000 \\
\hline & & post-test 1 & $-48,7500 *$ & 1,8139 & 0,000 \\
\hline & & post-test 2 & $-48,5333 *$ & 1,8139 & 0,000 \\
\hline & & post-test 3 & $-48,9750 *$ & 1,8139 & 0,000 \\
\hline & post-test 1 & pre-test 1 & $48,8833^{*}$ & 1,8139 & 0,000 \\
\hline & & pre-test 2 & $49,3250 *$ & 1,8139 & 0,000 \\
\hline & & pre-test 3 & $48,7500^{*}$ & 1,8139 & 0,000 \\
\hline & & post-test 2 & 0,2167 & 1,8139 & 1,000 \\
\hline & & post-test 3 & $-0,2250$ & 1,8139 & 1,000 \\
\hline & post-test 2 & pre-test 1 & $48,6667 *$ & 1,8139 & 0,000 \\
\hline & & pre-test 2 & $49,1083 *$ & 1,8139 & 0,000 \\
\hline & & pre-test 3 & $48,5333 *$ & 1,8139 & 0,000 \\
\hline & & post-test 1 & $-0,2167$ & 1,8139 & 1,000 \\
\hline & & post-test 3 & $-0,4417$ & 1,8139 & 1,000 \\
\hline & post-test 3 & pre-test 1 & $49,1083 *$ & 1,8139 & 0,000 \\
\hline & & pre-test 2 & $49,5500 *$ & 1,8139 & 0,000 \\
\hline & & pre-test 3 & $48,9750 *$ & 1,8139 & 0,000 \\
\hline & & post-test 1 & 0,2250 & 1,8139 & 1,000 \\
\hline & & post-test 2 & 0,4417 & 1,8139 & 1,000 \\
\hline
\end{tabular}

*. The mean difference is significant at the 0.05 level. 
306JINOTEP (Jurnal Inovasi dan Teknologi Pembelajaran) Kajian dan Riset dalam Teknologi Pembelajaran Vol.8, No.3, November 2021, Hal. 299-309

The normally distributed and homogenious data were analyzed using ANOVA. The ANOVA table show that the value of sig between groups $=0.000<\alpha=0.05$. The results of the ANOVA statistical analysis represents that $\mathrm{H} 0$ was rejected or the difference between the pre-test and post-test scores was significant $(\mathrm{P}=0.000)$. This indicates that students' communication skills in English before and after the implementation of the VCL changed significantly. The results of students' communication skills in English scores analysis are presented in Table 3.

The results of Pairwise Comparison analysis using Bonferroni showed that the sig value between O1(pre-test 1), O2 (pre-test 2), and $\mathrm{O} 3$ (pre-test 3 ) or between $\mathrm{O} 4$ (post-test 1), O5 (post-test 2), and O6 (post-test 3) were 1.000. Specifically, the sig value between the pre-test 1 and pre-test 2 or pre-test 1 and pretest 3 is 1.000 .

Likewise, 1.000 is the sig value between the post-test 1 and post-test 2 or posttest 1 and post-test 3 . That score indicates that students' communication skills in English before (between $\mathrm{O} 1, \mathrm{O} 2$, and $\mathrm{O} 3$ ) and after (between $\mathrm{O} 4, \mathrm{O} 5$, and O6) the implementation of VCL are not significantly different. Whereas, the sig value between $\mathrm{O} 1$ and $\mathrm{O} 4, \mathrm{O} 1$ and $\mathrm{O} 5$, $\mathrm{O} 1$ and $\mathrm{O} 6, \mathrm{O} 2$ and $\mathrm{O} 4, \mathrm{O} 2$ and $\mathrm{O} 5, \mathrm{O} 2$ and $\mathrm{O} 6$, $\mathrm{O} 3$ and $\mathrm{O} 4, \mathrm{O} 3$ and $\mathrm{O} 5, \mathrm{O} 3$ and $\mathrm{O} 6$ were 0,000 . The score between pre-tests and post-tests show that the students' communication skills in English before and after the implementation of VCL are significantly different $(\mathrm{P}=0.000)$. This strengthen the result that $\mathrm{HO}$ is rejected. The VCL between the two schools virtually can improve students' communication performance. The summary of the pairwise comparison analysis result is presented in Table 4 .

\section{DISCUSSION}

From the pre and post-test results, the use of the VCL method managed to enhance the communication ability among the primary Thai students in two different schools. In the pre-test scores, most students got around 33\% in each criteria (pronunciation, grammar, vocabulary, fluency, and comprehension). This indicated that the conventional method was not effective to improve students' English communication ability. After the implementation of the VCL method, the three post-test showed an increasing scores significantly. The twelve students got around $81 \%$ for each criteria in their post-tests. This showed that the VCL method managed to reinforce the pronunciation, grammar, vocabulary, fluency, and comprehension learned among the students, which represents to the aim of this study. Undeniably, Hernandez, Marcedes, and Pablo (2014) stated that, collaborative learning makes students able to express their ideas, articulate thinking, develop representations, elaborate, and engage in a social process of students' new knowledge. It allows students to learn from others, about the way how to speak, pronunciation, vocabulary, grammar, and followed by its fluency and comprehension. Besides, the classroom situation showed that students were enthusiastic during the classes. The virtual classes with different schools created a new environment that enhance students interest in learning. Supported by Kawinkoonlasate (2020) that virtual learning can overcome the students' boring matter effectively, interest, and bring them to the new learning environment.The students from other schools who become their new friends motivated them to learn more about each other.

The student number who volunteered to perform showed that the VCL had achieved its potential in encouraging students motivation and confidence in performing the communication ability in front of the classes virtually. The total students' number who volunteered to perform during the conventional method were less than 2 students in each communication test. It indicates that the students were not confident enough with their ability in English communication. It also shows that the students were not accustomed to communicate using English. However, the data of students number who volunteered to perform, after the VCL method treatments are almost all students. This represents the students' confidence were improve significantly. Almost all students were confident in their 
pronunciation, vocabulary, grammar, fluency, and comprehension to perform their English communication ability in front of the classes. This also shows that the students were accustomed to communicate using English.

Apart from those, Thai primary students were interested in learning English in the new environment and new friends from the other schools. It can also improve the knowledge of English teaching-learning activities from both schools. Those are beneficial for both schools, English teachers, and also students to improve student's communication ability, English teachers' knowledge of English teachinglearning methods, and then it will benefit the school as well.

\section{CONCLUSION}

The implementation of Virtual Collaborative Learning (VCL) can help to improve the students' communication ability. This study proved that VCL becomes an effective methodology in teaching English for primary school in Thailand as the data collected. The data collected showed that the most of the students had the confidence to perform in front of people, aside from having better communication ability; in which advanced the students' interest in learning active skills in English. The students' motivation level was improved marked by students' enthusiasm on the use of VCL between two different schools in learning communication during the class. Students got a new environment of learning through virtual learning. The collaboration between the two schools enhanced students interest in learning with new friends. In fact, according to pre-test data, post-test data and ANOVA test, VCL was better appropriate learning methods implemented in Bansubjaroen School and Wangnampu School, Thailand during virtual learning compared to the conventional learning. As for teachers, it provides a new alternative learning method for a students-centered learning environment where students can collaborate each other in two or more schools virtually. The teacher's involvement was decreasing and the students' autonomy was increasing during the process of learning. The role of the teacher is to guide and monitor the activities. Thus, VCL shows relevance improvement in students communication ability and confidence as one of the best methodology in an active, interesting, and effective way. As suggestions for future researches, it would be interesting to see the implementation of VCL in the wider respondents in different schools using other virtual applications.

\section{REFERENCES}

Adianto, S. (2020). Penerapan Scientific dan Cooperative Learning dengan Quis Online untuk Meningkatkan Hasil Belajar Siswa Sekolah Dasar. JINOTEP (Jurnal Inovasi Dan Teknologi Pembelajaran): Kajian Dan Riset Dalam Teknologi Pembelajaran. 7 (1), 57-65. Doi: 10.17977/um031v7i12020p057.

Al Hosni, S. (2014). Speaking Difficulties Encountered by Young EFL Learners. International Journal on Studies in English Language and Literature, 2 (6), 22-30. https://arcjournals.org.

Anderson, K. (2006). Using Online Discussions to Provide an Authentic Learning Experience for Professional Recordkeepers. Tony Herrington \& Jan Herrington, Authentic Learning Environment in Higher Education, Hershey.214-223. PA: Information Science Publishing. doi: 10.4018/978-1-59140-5948.ch016.

Berns, A., Rodriguez, F., Gomez, R. (2013). Collaborative learning in 3-D virtual environments. Global Perspectives on Computer-Assisted Language Learning Glasgow. United Kingdom: Papers.

Biyaem, S. (1997). Learner Training: Changing roles for a Changing World, Educational Innovation for Sustainable Development. 3rd UNESCOACEID International Conference. Bangkok.

Chandra, R. (2015). Collaborative Learning for Educational Achievement. Journal of Research and method in Education.5 (2). 1-4. doi: 10.9790/7388-052XXXXX.

Cho, Y.H., Lim, K.Y. (2017). Effectiveness of collaborative learning with $3 \mathrm{D}$ virtual worlds. Br. J. Edu. Technol. 48(1), 202-211. doi: 10.1111/bjet.12356.

Cook, T. D., Campbell, D. T., \& Day, A. (1979). Quasi-experimentation: Design \& analysis issues for field settings. Vol. 351. Boston: Houghton Mifflin.

Cottell, Philip G. Jr. and Barbara, M. J. (1994). Complex Cooperative Learning Structures for College and University Courses. To Improve the Academy. 304. Retrieved from:https://digitalcommons.unl.edu/podimpro veacad $/ 304$ 
308JINOTEP (Jurnal Inovasi dan Teknologi Pembelajaran) Kajian dan Riset dalam Teknologi Pembelajaran Vol.8, No.3, November 2021, Hal. 299-309

Daar, G., \& Nasar, I. (2021). Teachers Challenges in The Learning Process During The Covid-19 Pandemic in Rural Areas. JINOTEP (Jurnal Inovasi Dan Teknologi Pembelajaran): Kajian Dan Riset Dalam Teknologi Pembelajaran, 8 (2), 186-193. https://doi.org/10.17977/um031v8i22021p186

Davis, Keith \& John N. (2004). Perilaku Dalam Organisasi. ed. Ketujuh. Jakarta. Erlangga.

Djonnaidi, S., Wahyuni, N., \& Nova, F. (2021). Pengaruh Penerapan Media Poster Digital dalam Pembelajaran Daring di Masa Pandemi terhadap Kemampuan Berbicara Siswa di Politeknik Negeri Padang. JINOTEP (Jurnal Inovasi Dan Teknologi Pembelajaran): Kajian Dan Riset Dalam Teknologi Pembelajaran, 8 (1), 38-46. https://doi.org/10.17977/um031v8i12021p038

Fitriasari, N.S. Et.al. (2020). Pembelajaran Kolaboratif Berbasis Online. Jurnal Teknologi Informasi dan Komunikasi. 10 (1). 77-86. doi: dx.doi.org/10.35586/inspir.v10i1.2564.

Guitert, M. (2011). Time Management in Virtual Collaborative Learning: The Case of the Universitat Oberta de Catalunya (UOC). eLC Research Paper Series, 2, 5-16. https://elcrps.uoc.edu

Harsley, R., Fossati, D., Di Eugenio, B., Green, N. (2017). Interactions of individual and pair programmers with an intelligent tutoring system for computer science. Paper Presented at the Proceedings of the Conference on Integrating Technology into Computer Science Education. ITiCSE, 285-290. doi: 10.1145/3017680.3017786.

Hernandez, N., Marcedes G., Pablo M. (2014). Planning Collaborative Learning in Virtual Environments. Media Education Research Journal. $21 \quad$ (42). 25-32. doi: http://dx.doi.org/10.3916/C42-2014-02.

Hernández-Sellés, N. and Muñoz-Carril, P.C. (2012). Trabajo colaborativo en entornos elearning $y$ desarrollo de competencias transversales de trabajo en equipo: Análisis del caso del Máster en Gestión de Proyectos en Cooperación Internacional. Madrid: CSEU.

Homan, G., and Macpherson, A. (2005). E-learning in the corporate university. Journal of European Industrial Training, 29(1), 75-99. doi:10.1108/03090590510576226.

Ibáñez, M.B., García Rueda, J.J., Maroto, D., Delgado Kloos, C. (2013). Collaborative learning in multi-user virtual environments. $J$. Netw. Comput. Appl. 36(6), 1566-1576 (2013). doi: $10.1016 /$ j.jnca.2012.12.027.

Jaiyai, S., et al. (2005). The existing situations and Problems Relating to Foreign Language Teaching and Learning in the Northeastern part of Thailand (Educational Region 5). The Thailand Research Fund.

Januariza, Y. and Suswati H. (2016). Students' Anxiety in Learning English. International Seminar on English Language and Teaching. 4 (2). 468-474. http://ejournal.unp.ac.id/.

Johnson, D., Johnson, R. \& Holubec, E. (1993). El aprendizaje cooperativo en el aula. Barcelona: Paidós

Jhonson, D.W., Jhonson, R. T., \& Stanne, M. B. (2000). Cooperative Learning Methods: A Meta-Analysis. Minneapolis: University of Minnesota.

Kawinkoonlasate, P. (2020). Online Language Learning for Thai EFL Learners: An Analysis of Effective Alternative Learning Methods in Response to the Covid-19 Outbreak. Canadian Center of Science and Education. 13 (12). 1526. doi: 10.5539/elt.v13n12p15.

Khatib, F. M. M. And Nooreiny M. (2014). SelfEficiency Perception of Oral Communication Ability among English as a Second Language (ESL) Technical Students. Social and Behavioral Science. 204. 98-104. doi: 10.1016/j.sbspro.2015.08.121.

Leedy, P. D. and Ormrod, J. E. (2005). Practical Research Planning and Design. Practice Hall. Upper Saddle River, NJ.

Loes, C.N. et al. (2017). Does Collaborative Learning Influence Persistence to the Second Year of College?. The Journal Of Higher $\begin{array}{llll}\text { Education. } & 88 & \text { (01). } & 62-84 .\end{array}$ http://dx.doi.org/10.1080/00221546.2016.1243 942.

Matthews, B. \& Ross, L. (2010). Belajar dan Pembelajaran. Jakarta: Rineka Cipta.

Ningsih, S. (2020). Persepsi Mahasiswa Terhadap Pembelajaran Daring Pada Masa Pandemi Covid-19. JINOTEP (Jurnal Inovasi Dan Teknologi Pembelajaran): Kajian Dan Riset Dalam Teknologi Pembelajaran, 7 (2), 124132. https://doi.org/10.17977/um031v7i22020p124.

Palos. R. and Merima C. P. (2014). Preceived Inportance of Communication Skills and Their Predictive Value for Academic Performance. Revista de Cercetare si Intervintie Sociala. 46. 85-98. http://www.rcis.ro.

Prapphal, K. (2003). English proficiency of Thai learners and directions of English teaching and learning in Thailand. Journal of English Language Studies, 1(1), 6-12. https://jsel@arts.tu.ac.th.

Punthumasen, P. (2007). International Program for Teacher Education: An Approach to Tackling Problems of English Education in Thailand. The 11th UNESCO-APEID international conference. Retrieved from 
http://www.worldreform.com/pub/paperies $13 \mathrm{~d}$ ec07.pdf

Purcher, P., Hofler, M., Pirker, J., Tomes, L., Ischebeck, A., Gutl, C. (2016). Individual versus collaborative learning in a virtual world. Paper Presented at the International Convention on Information and Communication Technology, Electronics and Microelectronics. 824-828. doi: 10.1109/mipro.2016

Rao, P. S. (2019). The importance of speaking skills in English Classroom. Alford Council of International English \& Literature Journal (ACIELJ). 2 (2). 6-18. www.acielj.com.

Roberts, T. (2005). Computer-Supported Collaborative Learning in Higher Education: An introduction. In T.S. ROBERTS (Ed.), Computer-Supported Collaborative Learning in Higher Education. 1-18. Hershey: Idean Group Publishing.

Tadesse, S. and Worku M. (2020). The Impac of Covid-19 Pandemic on Education System in
Developing Countries: A Rivew. Open Journal on Science. 8. 159-170. doi: 10.4236/jss.2020.810011.

Xin, T. C. and Yunus, M. Md. (2019). The Effects of Kagan Cooperative Learning Structures in Teaching Subject-Verb Agreement among Rural Sarawak Learners. Arab World English Journal (AWEJ). $10 \quad$ (2). doi: http://dx.doi.org/10.2139/ssrn.3418106.

Yonas, M. and Mitike M. (2020). An Explorative Study to Document Challenges of Virtual Teaching and Learning Due to COVID-19 among Graduate Students at The SPH, CHS, Addis Ababa University at 2020. Research Square. 1-13. Doi: https://doi.org/10.21203/rs.3.rs-89266/v1

Yuan, J. and Kim, C. (2014). Guidelines for facilitating and develipment of learning communities in online courses. Journal of Computer Assissted Learning. 30(3). 220-232. Doi:10.1111/jcal.12042. 